\title{
ANALISIS PENGARUH PAD, DAU DAN DAK TERHADAP BELANJA MODAL DAN BELANJA BARANG DAN JASA KOTA DAN KABUPATEN DI PROVINSI JAWA TIMUR TAHUN 2006-2012
}

\author{
Sugeng Haryanto \\ E-mail : p3et@yahoo.com
}

\begin{abstract}
Decentralized system of local government put as executor and promoter of development in the area to organize and define their own regional development activities in accordance with the priority needs of the local community. Local governments have the right and authority to use the vast financial resources in accordance with its needs and aspirations of the people who thrive in the area. This study aimed to analyze the effect of PAD and transfer from the central government in the form of DAU and DAK towards capital expenditure and spending on goods and services. This study took a sample of the cities and counties in the province of East Java in 2006-2012. The analysis technique used is multiple regression analysis showed that simultaneous PAD, DAU and DAK effect on capital expenditures and also to Goods and Services expenditures. Partially PAD, DAU and $D A K$ effect on capital expenditures. While PAD and DAU partially affect Expenditure on Goods and Services, but does not affect the DAK Goods and Services expenditures.
\end{abstract}

Keywords: PAD, DAU, DAK, Capital expenditure, goods and services expenditure.

\section{PENDAHULUAN}

Sejak di undangkannya UU Nomor 22 Tahun 1999 tentang Pemerintah Daerah yang kemudian direvisi dengan UU Nomor 32 Tahun 2004, engamanatkan bahwa daerah diberi kewenangan yang luas untuk mengurus rumah tangganya sendiri dengan sesedikit mungkin campur tangan pemerintah pusat. Undangundang tersebut merupakan wujud dari otonomi daerah. Diberlakukannya UU No. 32 dan UU No. 33 Tahun 2004 memberikan kewenangan dan keleluasaan yang lebih luas bagi Pemerintah Kabupaten/Kota sebagai pelaksana dan promotor pembangunan di daerah untuk mengatur dan menentukan sendiri kegiatan pembangunan wilayah yang sesuai dengan prioritas kebutuhan masyarakat setempat. Pemerintah daerah mempunyai hak dan kewenangan yang luas untuk menggunakan sumber-sumber keuangan yang dimilikinya sesuai dengan kebutuhan dan aspirasi masyarakat yang berkembang di daerah. Daerah memiliki

Sugeng Haryanto, Dosen Program D3Keuangan dan Perbankan Universitas Merdeka Malang 
kewenangan untuk menentukan alokasi sumber daya ke dalam belanja-belanja dengan menganut asas kepatutan, kebutuhan dan kemampuan daerah.

Dalam UU No. 32 Tahun 2004 disebutkan bahwa untuk pelaksanaan kewenangan pemerintah daerah, pemerintah pusat akan mentransfer Dana Perimbangan yang terdiri dari Dana Alokasi Umum (DAU), Dana Alokasi Khusus (DAK), dan bagian daerah dari Dana Bagi Hasil (DBH) yang terdiri dari pajak dan sumber daya alam. Disamping dana perimbangan tersebut, pemerintah daerah mempunyai sumber pendanaan sendiri berupa Pendapatan Asli Daerah (PAD), pembiayaan, dan lain-lain pendapatan. Kebijakan penggunaan semua dana tersebut diserahkan kepada pemerintah daerah. Dana transfer dari pemerintah pusat diharapkan digunakan secara efektif dan efisien oleh pemerintah daerah untuk meningkatkan pelayanannya kepada masyarakat.

Otonomi daerah merupakan bentuk dari desentralisasi kekuasaan dalam penyelenggaran pemerintahan. Otonomi daerah yang secara resmi diberlakukan tahun 2001 menentukan bahwa konsentrasi daerah otonom berada di kota atau kabupaten dan bukan di provinsi. Hal ini terlihat dari proporsi Dana Alokasi Umum (DAU) 10\% dan $90 \%$ dari DAU yang ditetapkan, yaitu 25\% dari pendapatan dalam negeri APBN. Hal ini menunjukkan betapa pentingnya peran kota atau kabupaten dalam otonomi daerah, sebagai titik pertumbuhan ekonomi.

Dalam menjalankan otonomi daerah, pemerintah daerah dituntut untuk menjalankan roda pemerintahan secara efisien dan efektif, mampu mendorong peran serta masyarakat dalam pembangunan, serta meningkatkan pemerataan dan keadilan dengan mengembangkan seluruh potensi yang dimiliki oleh masingmasing daerah. Banyak hal yang ingin dicapai melalui otonomi daerah. Dalam bidang ekonomi yang hendak dicapai melalui desentralisasi adalah mewujudkan kesejahteraan melalui penyediaan layanan publik yang lebih merata dan memperpendek jarak antara penyedia layanan publik dan masyarakat lokal.

Dalam era desentralisasi fiskal diharapkan terjadinya peningkatan pelayanan diberbagai sektor terutama sektor publik di daerah, baik kota maupun kabupaten. Peningkatan layanan publik ini diharapkan dapat meningkatkan daya tarik bagi investor untuk menanamkan investasinya di daerah. Harapan ini tentu saja dapat terwujud apabila ada upaya serius dari pemerintah dengan memberikan berbagai fasilitas pendukung yang mampu menjadi daya tarik investor.

Pembangunan infrastruktur di kota atau kabupaten merupakan salah satu faktor yang sangat penting sebagai daya tarik investor, selain iklim investasi yang kondusif di suatu daerah. Daerah dituntut untut mampu menyediakan dan meningkatkan ketersediaan infrastruktur yang memadai, baik kuantitas maupun kualitas.

Peningkatan investasi di daerah, akan berpengaruh secara signifikan terhadap pertumbuhan ekonomi di daerah tersebut. Banyaknya investor yang menanamkan modalnya di suatu kota atau kabupaten akan berdampak positif pada pertumbuhan ekonomi daerah tersebut. Investasi yang ada di suatu daerah akan mampu menyediakan lapangan kerja baru, sehingga mampu menekan angka pengangguran. Sehingga pada akhirnya juga akan mampu menambah pendapatan asli daerah (PAD) melalui pajak.

Pemerintah daerah mempunyai peran yang strategis dalam menyediakan infrastruktur. Konsekuensinya, pemerintah perlu untuk memberikan alokasi belanja 
yang lebih besar untuk tujuan ini. Pergeseran komposisi belanja merupakan upaya logis yang dilakukan Pemda dalam rangka meningkatkan tingkat kepercayaan publik yang dapat dilakukan dengan peningkatan investasi modal dalam bentuk aset tetap, yakni peralatan, bangunan, infrastruktur dan harta tetap lainnya. Dengan meningkatnya pengeluaran modal diharapkan dapat meningkatkan pelayanan publik karena hasil dari pengeluaran belanja modal adalah meningkatnya aset tetap daerah yang merupakan prasyarat dalam memberikan pelayanan publik oleh Pemerintah daerah.

Peningkatan alokasi belanja modal dalam bentuk aset tetap seperti infrastruktur, peralatan dan infrastruktur sangat penting untuk meningkatkan produktivitas perekonomian karena semakin tinggi belanja modal semakin tinggi pula produktivitas perekonomian. Selain belanja modal yang merupakan pengeluaran daerah yang cukup berpengaruh terhadap peningkatan roda ekonomi daerah adalah belanja barang dan jasa yang dilakukan oleh pererintah daerah.

Pemanfaatan belanja hendaknya dialokasikan untuk hal-hal yang produktif seperti untuk melakukan aktivitas pembangunan dan juga untuk program-program pelayanan publik (Saragih, 2003; Stine, 1994).

Keberhasilan desentralisasi akan sangat dipengaruhi oleh kesiapan suatu daerah. Desentralisasi fiskal akan memberikan kewenangan yang lebih besar dalam pengelolaan daerah, namun permasalahan yang timbul adalah tingkat kesiapan fiskal daerah yang berbeda-beda. Hal ini karena kualitas SDM, yang berbeda pula, selain munculnya kota atau kabupten baru yang merupakan pemekaran. Adi (2005) menemukan disparitas antar kota atau kabupten yang tinggi. Nanga (2005) mengindikasikan terjadinya ketimpangan fiskal antar daerah dan bisa jadi hal ini mempengaruhi tingkat pertumbuhan ekonomi daerah.

Kondisi keuangan daerah kota dan kebupaten di Indonesia mempunyai tingkat varian yang tinggi. Disparitas kemampuan keuangan antar daerah merupakan sesuatu yang alami yang terjadi di semua Negara di dunia. Setiap daerah mempunyai kemampuan keuangan yang tidak sama dalam mendanai kegiatan-kegiatannya, hal ini menimbulkan ketimpangan fiskal antara satu daerah dengan daerah lainnya. Pemerintah Pusat dalam upaya mengurangi ketimpangan fiskal telah mengalokasikan dana yang bersumber dari APBN untuk mendanai kebutuhan daerah dalam pelaksanaan desentralisasi. Salah satu dana perimbangan dari pemerintah ini adalah Dana Alokasi Umum (DAU) yang pengalokasiannya menekankan aspek pemerataan dan keadilan yang selaras dengan penyelenggaraan urusan pemerintahan (UU 32/2004). Dengan adanya transfer dana dari pusat ini diharapkan pemerintah daerah bisa lebih mengalokasikan PAD yang didapatnya untuk membiayai belanja modal di daerahnya.

Dalam upaya optimalisasi belanja daerah, maka seiring dengan reformasi sektor publik yang disertai adanya tuntutan demokratisasi menyebabkan aspek transparansi dan akuntabilitas menjadi hal penting dalam pengelolaan pemerintah termasuk di bidang pengelolaan keuangan negara maupun daerah. Akuntabilitas publik adalah pemberian informasi dan pengungkapan seluruh aktivitas dan kerja finansial Pemerintah Daerah kepada pihak-pihak yang berkepentingan (Mardiasmo, 2002). Pengamat ekonomi, pengamat politik, investor, hingga rakyat mulai memperhatikan setiap kebijakan dalam pengelolaan keuangan. 
Provisni Jawa Timur merupakan salah satu provinsi dengan jumlah kabupaten dan kota yang cukup besar. Kondisi daerah di Jawa Timur juga menunjukkan sangat bervariatif, dengan perbedaan antara kota besar dengan kota atau kabupaten yang relative kecil secara ekonomi tetapi secara wilayah cukup luas. Daerah kota di Jawa Timur secara garis besar terdiri dari daerah dengan basis industri yang kuat, seperti Surabaya, Sidoarjo, Gresik dan sebagainya dan daerah dengan basis pertanian. Perbedaan kondisi yang cukup bervariatif tersebut tentunya membuat akan berpengaruh pada sumber-sumber pendapatan dan juga belanja yang dikeluarkan oleh Pemerintah Daerah.

Beberapa penelitian terkait dengan DAU, PAD dan DAK dalam perekonomian daerah menunjukkan hasil-hasil yang berbeda-beda. Syukry Halim (2003) meneliti Pengaruh DAU dan PAD terhadap (total) Belanja Pemerintah Daerah di 90 kabupaten/kota di Jawa dan Bali menunjukkan bahwa secara terpisah, DAU dan PAD berpengaruh signifikan terhadap (total) Belanja Daerah. Herdarmin (2012) Belanja modal berpengaruh positif terhadap peretumbuhan ekonomi daerah. Setiyawati dan Hasah (2007) menunjukkan bahwa PAD berpengarub positif terhadap pertumbuhan ekonomi sedangan DAU berpengaruh negative terhadap DAU. Sedangkan hasil penelitian Nugraeni (2011) menunjukkan DAU, DAK dan PAD merupakan faktor yang signifikan untuk prediksi Anggaran Belanja Daerah pemerintah daerah kabupaten/kota di Indonesia.

Berdasarkan hasil penelitian yang menunjukkan yang berbeda tersebut, maka penelitian tentang pengaruh PAD, DAU dan DAK terhadap belanja barang dan jasa dan belanja modal tetap menjadi kajian yang menarik. Berdasarkan latar belakang di atas, maka permasalahan dalam penelitian ini dapat dirumuskan sebagai berikut:

a. Bagaimana pengaruh masing-masing variabel PAD, DAU dan DAK terhadap Belanja Modal Kota dan Kabupaten di Provinsi Jawa Timur.

b. Bagaimana pengaruh masing-masing variabel PAD, DAU dan DAK terhadap Belanja Barang dan Jasa Kota dan Kabupaten di Provinsi Jawa Timur.

c. Bagaimana pengaruh variabel PAD, DAU dan DAK secara bersama-sama terhadap Belanja Modal Kota dan Kabupaten di Provinsi Jawa Timur.

d. Bagaimana pengaruh variabel PAD, DAU dan DAK secara bersama-sama terhadap Belanja Barang dan Jasa Kota dan Kabupaten di Provinsi Jawa Timur.

\section{TINJAUAN PUSTAKA}

\section{Belanja Daerah}

Peraturan Menteri Dalam Negeri Nomor 13 Tahun 2006 Tentang Pedoman Pengelolaan Keuangan Daerah, kelompok Belanja Tidak Langsung terdiri dari belanja pegawai, belanja bunga, belanja subsidi, belanja hibah, bantuan sosial, belanja bagi hasil, bantuan keuangan, dan belanja tidak terduga. Dalam belanja langsung yang terdapat dalam Pasal 50, kelompok belanja langsung dari suatu kegiatan dibagi menurut jenis belanja yang terdiri dari belanja pegawai, belanja barang dan jasa, dan belanja modal. 
Halim (2002:72) "Belanja modal merupakan pengeluaran pemerintah daerah yang manfaatnya melebihi satu tahun anggaran dan akan menanambah aset atau kekayaan daerah, dan selanjutnya akan menambah belanja yang bersifat rutin, seperi biaya operasi dan biaya pemeliharaan". Belanja Modal adalah pengeluaran yang dilakukan dalam rangka pembentukan modal yang sifatnya menambah aset tetap/inventaris yang memberikan manfaat lebih dari satu periode akuntansi, termasuk di dalamnya adalah pengeluaran untuk biaya pemeliharaan yang sifatnya mempertahankan atau menambah masa manfaat, meningkatkan kapasitas dan kualitas aset. Belanja Modal sendiri terdiri dari: (1) Belanja Modal Tanah, (2) Belanja Modal Peralatan dan Mesin, (3) Belanja Modal Gedung dan Bangunan, (4) Belanja Modal Jalan, Irigasi dan Jaringan, dan (5) Belanja Modal Fisik Lainya. Sesuai dengan Peraturan Direktur Jenderal Perbendaharaan nomor PER66/PB/2005 tanggal 28 Desember 2005 tentang Mekanisme Pelaksanaan Pembayaran atas Beban Anggaran Pendapatan dan Belanja Negara, pengeluaran untuk beban Belanja Modal dilakukan melalui mekanisme pembayaran langsung.

Dalam konteks pengelolaan keuangan daerah, pengalokasian belanja modal sangat berkaitan dengan perencanaan keuangan jangka panjang, terutama pembiayaan untuk pemeliharaan aset tetap yang dihasilkan dari belanja modal tersebut. Konsep multi-term expenditure framework (MTEF) menyatakan bahwa kebijakan belanja modal harus memperhatikan kemanfaatan (usefulness) dan kemampuan keuangan pemerintah daerah (budget capability) dalam pengelolaan aset tersebut dalam jangka panjang (Allen dan Tommasi, 2001). Hal ini berarti bahwa pengelolaan aset terkait dengan belanja pemeliharaan, dan sumber pendapatan atau lebih luas sumber pendanaan.

Anggaran ini sebenarnya dimaksudkan untuk memenuhi kebutuhan publik akan sarana dan prasarana umum yang disediakan oleh pemerintah daerah. Namun, adanya kepentingan politik dari lembaga legislatif yang terlibat dalam penyusunan proses anggaran menyebabkan alokasi belanja modal terdistorsi dan sering tidak efektif dalam memecahkan masalah di masyarakat (Keefer dan Khemani, 2003). Peningkatan alokasi belanja modal dalam bentuk aset tetap seperti infrastruktur, peralatan dan infrastruktur sangat penting untuk meningkatkan produktivitas perekonomian karena semakin tinggi belanja modal semakin tinggi pula produktivitas perekonomian. Saragih (2003) menyatakan bahwa pemanfaatan belanja hendaknya dialokasikan untuk hal-hal yang produktif seperti untuk melakukan aktivitas pembangunan. Sejalan dengan pendapat tersebut. Darwanto dan Yustikasari (2006) menyatakan bahwa penerimaan pemerintah hendaknya lebih banyak untuk program-program pelayanan publik. Kedua pendapat ini menyirat pentingnya mengalokasikan belanja untuk berbagai kepentingan publik. Pemberian otonomi daerah berpengaruh terhadap pertumbuhan ekonomi suatu daerah karena memberikan kebebasan kepada pemerintah daerah untuk membuat rencana keuangannya sendiri dan membuat kebijakan-kebijakan yang dapat berpengaruh pada kemajuan daerahnya.

\section{Dana alokasi Umum (DAU)}

Setiap daerah mempunyai kemampuan keuangan yang tidak sama dalam mendanai kegiatan-kegiatannya, hal ini menimbulkan ketimpangan fiskal antara satu daerah dengan daerah lainnya. Oleh karena itu, untuk mengatasi ketimpangan 
fiskal ini Pemerintah mengalokasikan dana yang bersumber dari APBN untuk mendanai kebutuhan daerah dalam pelaksanaan desentralisasi. Salah satu dana perimbangan dari pemerintah ini adalah Dana Alokasi Umum (DAU) yang pengalokasiannya menekankan aspek pemerataan dan keadilan yang selaras dengan penyelenggaraan urusan pemerintahan (UU 32/2004).

Dana Alokasi Umum (DAU) adalah dana yang berasal dari APBN (Anggaran Pendapatan dan Belanja Negara) yang dialokasikan dengan tujuan pemerataan kemampuan keuangan antar daerah untuk membiayai kebutuhan pengeluarannya dalam rangka pelaksanaan desentralisasi. Pemerintah pusat memberikan bantuan berupa DAU yang besarnya sekurang-kurangnya 26\% dari penerimaan dalam negeri yang ditetapkan dalam APBN. Untuk daerah provinsi menerima sebesar $10 \%$ dari DAU yang ditetapkan, sedangkan kabupaten/ kota sebesar 90\%. Pengaturan lebih lanjut terhadap hal itu dituangkan dalam Peraturan Pemerintah Nomor 104 tahun 2000 yang menyatakan pembagian DAU kepada seluruh provinsi dan kabupaten. Pengaturan lebih lanjut terhadap DAU dituangkan dalam Peraturan Pemerintah Nomor 104 Tahun 2000 yang menyatakan pembagian DAU kepada seluruh provinsi dan kabupaten/kota di Indonesia

\section{Dana Alokasi Khusus (DAK)}

Dana Alokasi Khusus (DAK) adalah dana yang berasal dari APBN, yang dialokasikan kepada daerah untuk membantu membiayai kebutuhan khusus. Pengalokasian DAK memperhatikan ketersediaan dana dalam APBN, yang berarti bahwa besaran DAK tidak dapat dipastikan setiap tahunnya. DAK diberikan kepada daerah apabila daerah menghadapi masalah-masalah khusus. Menurut (Hairul Aswadi dalam Halim, 2001:58) menyatakan bahwa tujuan dari penggunaan DAK dapat diarahkan pada upaya untuk meningkatkan Indek Pembangunan Manusia (IPM) yang merupakan salah satu isu nasional yang perlu dituntaskan. Hal ini dikarenakan besarnya tingkat kemiskinan yang ada di daerah.

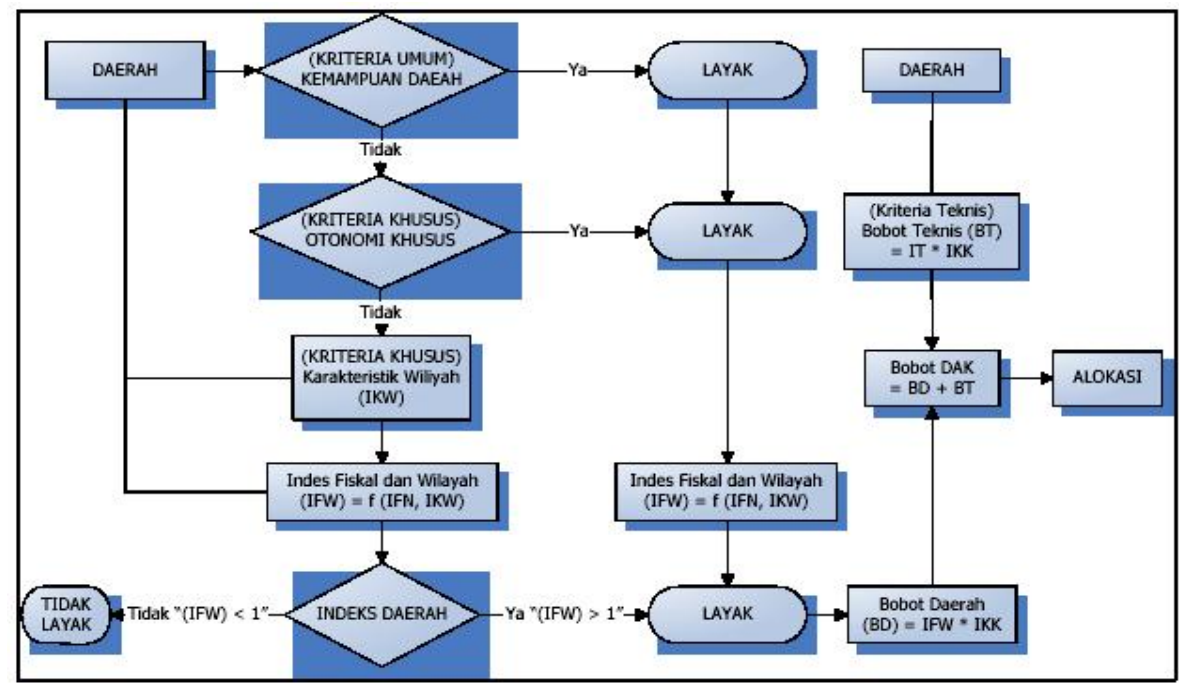

Gambar 1. Mekanisme Alokasi DAK 
Sumber: Ditjen Perimbangan Keuangan Pelengkap buku pegangan 2008, Penyelenggaraan Pemerintahan dan Pembangunan Daerah, hal.III-88 s.d. III-89

\section{Pendapatan Asli Daerah (PAD)}

Desentralisasi fiskal memberikan kewenangan yang besar kepada daerah untuk menggali potensi yang dimiliki sebagai sumber pendapatan daerah untuk membiayai pengeluaran daerah dalam rangka pelayanan publik. Berdasarkan Undang-Undang No. 32 Tahun 2004, salah satu sumber pendapatan daerah adalah Pendapatan Asli Daerah (PAD) yang terdiri dari hasil pajak daerah, hasil retribusi daerah, hasil pengelolaan kekayaan daerah yang dipisahkan dan lain-lain PAD yang sah. Peningkatan PAD diharapkan meningkatkan investasi belanja modal pemerintah daerah sehingga kualitas pelayanan publik semakin baik tetapi yang terjadi adalah peningkatan pendapatan asli daerah tidak diikuti dengan kenaikan anggaran belanja modal yang signifikan hal ini disebabkan karena pendapatan asli daerah tersebut banyak tersedot untuk membiayai belanja lainnya.

\section{Penelitian Terdahulu}

Penelitian Nugraeni (2011) menyatakan bahwa DAU, DAK dan PAD merupakan faktor yang signifikan untuk prediksi Anggaran Belanja Daerah pemerintah daerah kabupaten/kota di Indonesia. Hal ini sama dengan hasil penelitian yang dilakukan Paujiah di mana secara simultan antara PAD dan DAU memberikan pengaruh terhadap Belanja Modal. Ulum (2005) yang melakukan analisis selama 3 tahun dari tahun 2001-2003 dengan sampel 17 provinsi menunjukkan bahwa Dana perimbangan berpengaruh secara signifikan terhadap belanja daerah. Soeratno (2010) melakukan penelitian dengan Populasi seluruh kabupaten/kota provinsi di Indonesia, dengan sampel yang diambil pada penelitian ini meliputi 10 kabupaten/kota di Provinsi Jawa Barat yang terdiri dari 7 kabupaten dan 3 kotamadya. Penelitian ini dilakukan pada tahun 2005-2009 dengan data penelitian sebanyak 50 sampel kabupaten/kota di Jawa Barat, menunjukkan bahwa secara simultan Pendapatan Asli Daerah (PAD), Dana Alokasi Umum (DAU), dan Dana Alokasi Khusus (DAK) berimplikasi secara signifikan terhadap belanja daerah.

Studi yang dilakukan oleh Abdullah dan Halim (2004) menyimpulkan bahwa sumber pendapatan daerah berupa dana perimbangan berasosiasi positif terhadap belanja modal, sementara PAD tidak berasosiasi positif terhadap belanja modal. Hasil penelitian Harianto dan Adi (2007), Maharani (2007) maupun Putro (2011) menunjukkan hasil yang sama.

\section{Kerangka Pemikiran}

Kerangka penelitian yang dikembangkan dalam penelitian ini ditampilkan pada Gambar 2. 


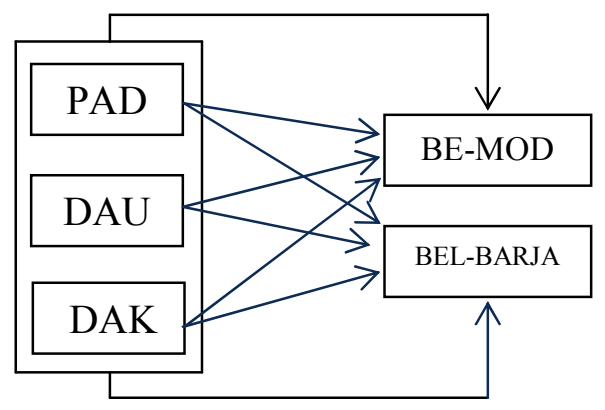

Gambar 2. Kerangka Pemikiran

Di mana:

PAD : Pendapatan Asli daerah

DAU : Dana Alokasi Umum

DAK : Dana Alokasi Khusus

BE-MOD : Belanja Modal

BEL-BARJA : Belanja Barang dan Jasa

\section{Hipotesis}

Mengacu pada landasan teori dan penelitian terdahulu, maka hipoteisis dalam penelitian ini dapat dirumuskan sebagai berikut:

a. $\mathrm{Ha}_{1}=\mathrm{PAD}$ berpengaruh secara signifikan terhadap belanja modal.

b. $\mathrm{Ha}_{2}=$ DAU berpengaruh secara signifikan terhadap belanja modal.

c. $\mathrm{Ha}_{3}=\mathrm{DAK}$ berpengaruh secara signifikan terhadap belanja modal

d. $\mathrm{Ha}_{4}=$ PAD berpengaruh secara signifikan terhadap belanja barang dan jasa.

e. $\mathrm{Ha}_{5}=\mathrm{DAU}$ berpengaruh secara signifikan terhadap belanja barang dan jasa.

f. $\mathrm{Ha}_{6}=\mathrm{DAK}$ berpengaruh secara signifikan terhadap belanja barang dan jasa.

g. $\mathrm{Ha}_{7}=\mathrm{PAD}, \mathrm{DAU}$ dan DAK secara simultasb berpengaruh secara signifikan terhadap belanja barang dan jasa.

h. $\mathrm{Ha}_{8}=\mathrm{PAD}$, DAU dan DAK secara simultan berpengaruh secara signifikan terhadap belanja modal.

\section{METODE}

\section{Definisi Operasional Variabel}

\section{Pendapatan Asli Daerah (PAD)}

Pendapatan Asli Daerah (PAD) merupakan penerimaan yang diperoleh daerah yang berasal dari sumber-sumber dalam wilayahnya sendiri yang dipungut berdasarkan peraturan daerah sesuai dengan peraturan perundang-undangan yang berlaku. Dalam penelitian ini PAD diukur dari total penerimaan pajak daerah, restribusi daerah, hasil perusahaan milik daerah dan hasil pengelolaan kekakayaan daerah yang dipisahkan dan lain-lain PAD yang sah. 


\section{Dana Alokasi Umum (DAU)}

Dana Alokasi Umum (DAU) merupakan dana yang berasal dari APBN yang dialokasikan dengan tujuan pemerataan kemampuan keuangan antar daerah untukmembiayai kebutuhan pengeluarannya dalam rangka pelaksanaan desentralisasi. DAU dalam penelitian ini diukur dari jumlah penerimaan transfer yang diberikan oleh pemerintah pusat kepada daerah kota atau kabupaten.

\section{Dana Alokasi Khusus (DAK)}

Dana Alokasi Khusus merupakan dana yang berasal dari APBN yang dialokasikan kepada daerah untuk membantu membiayai kebutuhan khusus. DAK dalam penelitian ini diukur dari jumlah penerimaan DAK yang diberikan oleh pemerintah pusat kepada pemerinath kota atau kabupaten.

\section{Belanja Barang dan Jasa}

Belanja barang dan jasa adalah pembelian barang dan jasa yang habis pakai untuk memproduksi barang dan jasa yang dipasarkan maupun yang tidak dipasarkan. Belanja barang dan jasa terdiri dari Belanja pengadaan barang dan jasa, Belanja pemeliharaan dan belanja perjalanan.

\section{Belanja Modal}

Belanja modal merupakan pengeluaran pemerintah daerah yang manfaatnya melebihi satu tahun anggaran dan akan menanambah aset atau kekayaan daerah, dan selanjutnya akan menambah belanja yang bersifat rutin, seperi biaya operasi dan biaya pemeliharaan. Belanja modal dalam penelitian ini diukur dari jumlah belanja barang modal yang dikeluarkan oleh masing-masing pemerintah daerah kota atau kabupaten.

\section{Sumber dan Jenis Data}

Sumber data dalam penelitian ini adalah data sekunder, yang diperoleh dari DirektoratJenderal Keuangan Daerah, Kementerian Dalam Negeri yang berupa data online yang adadi situs web http://djkd.depdagri.go.id.

Jenis Data yang digunakan dalam penelitian ini adalah data kuantitatif, yang berupa data tentang besarnya PAD, DAU, DAK, Belanja Modal dan Belanja Barang dan Jasa dari masing-masing Kota dan Kabupaten Di Jawa Timur dari Tahun 2006-2012.

\section{Populasi dan sampel}

Populasi dalam penelitian ini adalah seluruh Kota dan Kabupaten yang ada di Jawa Timur, yaitu sebanyak 38 daerah. Seluruh daerah Kota dan Kabupaten yang ada di Provinsi Jawa Timur dijadikan sampel penelitian. 
Tabel 1

Kota dan Kabupaten Di Provinsi Jawa Timur

\begin{tabular}{|r|l|r|l|}
\hline No & Daerah & No & Daerah \\
\hline 1 & Kab. Bangkalan & 20 & Kab. Pasuruan \\
\hline 2 & Kab. Banyuwangi & 21 & Kab. Ponorogo \\
\hline 3 & Kab. Blitar & 22 & Kab. Probolinggo \\
\hline 4 & Kab. Bojonegoro & 23 & Kab. Sampang \\
\hline 5 & Kab. Bondowoso & 24 & Kab. Sidoarjo \\
\hline 6 & Kab. Gresik & 25 & Kab. Situbondo \\
\hline 7 & Kab. Jember & 26 & Kab. Sumenep \\
\hline 8 & Kab. Jombang & 27 & Kab. Trenggalek \\
\hline 9 & Kab. Kediri & 28 & Kab. Tuban \\
\hline 10 & Kab. Lamongan & 29 & Kab. Tulungagung \\
\hline 11 & Kab. Lumajang & 30 & Kota Blitar \\
\hline 12 & Kab. Madiun & 31 & Kota Kediri \\
\hline 13 & Kab. Magetan & 32 & Kota Madiun \\
\hline 14 & Kab. Malang & 33 & Kota Malang \\
\hline 15 & Kab. Mojokerto & 34 & Kota Mojokerto \\
\hline 16 & Kab. Nganjuk & 35 & Kota Pasuruan \\
\hline 17 & Kab. Ngawi & 36 & Kota Probolinggo \\
\hline 18 & Kab. Pacitan & 37 & Kota Surabaya \\
\hline 19 & Kab. Pamekasan & 38 & Kota Batu \\
\hline
\end{tabular}

\section{Teknik Pengumpulan Data}

Teknik pengumpulan data yag digunakan dalam penelitian ini adalah dengan menggunakan teknik dokumentasi.

\section{Teknik Analisis Data}

Teknik analisis data yang digunakan dengan menggunakan regresi liniear berganda. Model regresi linear berganda sebagai berikut:

Di mana

$$
\begin{aligned}
& Y_{1}=\alpha+\beta_{1} X_{1}+\beta_{1} X_{1}+\beta_{2} X_{2}+\beta_{3} X_{3}+e \\
& Y_{2}=\alpha+\beta_{1} X_{1}+\beta_{1} X_{1}+\beta_{2} X_{2}+\beta_{3} X_{3}+e
\end{aligned}
$$

$\mathrm{Y}_{1} \quad=$ Belanja Modal

$\mathrm{Y}_{2} \quad=$ Belanja Barang dan Jasa

$\alpha \quad=$ Konstanta

$\square_{\square \square \square} \square$ Koefisien regresi

$\mathrm{X}_{1} \quad=$ Pendapatan Asli daerah (PAD)

$\mathrm{X}_{2}=$ Dana Alokasi Umum (DAU) 
150 MODERNISASI, Volume 9, Nomor 2, Juni 2013

$\mathrm{X}_{3}=$ Dana Alokasi Khusus (DAK)

e $\quad=$ Disturbance error

\section{PEMBAHASAN}

Tabel 2 rata-rata besarnya PAD kota dan kabupaten di Jawa Timur antara tahun 2006-2012 Rp. 102,284 juta. Surabaya merupakan Kota yang mempunyai PAD terbesar yaitu sebesar Rp. 1,215,298 juta, karena Surabaya merupakan Kota besar di mana sumber-sumber PAD sangat potensial. Hal ini tentunya berbanding terbalik dengan kabupaten yang tidak mempunyai potensi sumber PAD yang potensial, baik secara kualitas maupun kuantitas, seperti Kota Madiun, Ngawi, Kota Mojokerto, Kabupaten Pacitan, Kota Pasurun dan Kota Batu. Daerah-daerah tersebut PAD-nya kurang dari 30 milyar.

Kota Surabaya mempunyai belanja modal dan belanja barang dan jasa yang paling tinggi diantara kota dan kabupaten di Jawa Timur, hal ini tidak terlepas dari Kota Surabaya sebagai kota besar. Pengeluaran Belanja yang besar tercermin pada Belanja Modal dan Belanja Barang dan Jasa ditopang oleh besarnya PAD dan juga DAU Kota Surabaya. Besarnya rata-rata Belanja Modal dan Belanja Barang dan Jasa Kota Surabaya antara tahun 2006-2012 masing-masing sebesar Rp. 1,115,877 juta dan Rp. 1,002,875 juta. Sedangkan Kabupaten Trenggalek dengan pengeluaran Belanja Modan p. Rp. 87,550 juta. Kota Batu dan Madiun merupakan Kota dengan Belanja Barang dan Jasa yang paling kecil.

Tabel 2

Rata-Rata PAD, DAU, DAK, Belanja Modal dan Belanja Barang dan Jasa Kota dan Kabupaten Di Provinsi Jawa Timur Tahun 2006-2012 (Dalam Juta)

\begin{tabular}{|c|l|r|c|r|r|r|}
\hline NO & DAERAH & PAD & DAU & DAK & $\begin{array}{c}\text { BELANJA } \\
\text { MODAL }\end{array}$ & $\begin{array}{l}\text { BELANJA } \\
\text { BARANG } \\
\text { DAN } \\
\text { JASA }\end{array}$ \\
\hline 1 & $\begin{array}{l}\text { Kota } \\
\text { Surabaya }\end{array}$ & $1,165,125$ & 709,491 & 33,407 & $1,115,877$ & $1,002,875$ \\
\hline 2 & $\begin{array}{l}\text { Kab. } \\
\text { Sidoarjo }\end{array}$ & 293,505 & 688,763 & 38,463 & 328,201 & 269,311 \\
\hline 3 & $\begin{array}{l}\text { Kab. } \\
\text { Gresik }\end{array}$ & 166,460 & 525,152 & 39,477 & 170,011 & 156,235 \\
\hline 4 & $\begin{array}{l}\text { Kab. } \\
\text { Jember }\end{array}$ & 119,711 & 934,064 & 78,890 & 269,609 & 198,829 \\
\hline 5 & $\begin{array}{l}\text { Kota } \\
\text { Malang }\end{array}$ & 103,810 & 489,168 & 20,732 & 194,228 & 152,324 \\
\hline 6 & $\begin{array}{l}\text { Kab. } \\
\text { Malang }\end{array}$ & 101,043 & 985,861 & 76,399 & 351,510 & 190,358 \\
\hline 7 & $\begin{array}{l}\text { Kab. } \\
\text { Pasuruan }\end{array}$ & 87,176 & 631,681 & 66,036 & 218,265 & 215,837 \\
\hline 8 & Kab. & & & & & \\
\hline
\end{tabular}


Sugeng Haryanto, Analisis Pengaruh PAD, DAU, dan DAK... 151

\begin{tabular}{|c|c|c|c|c|c|c|}
\hline & Jombang & 80,628 & 602,693 & 40,609 & 173,802 & 154,205 \\
\hline 9 & Kab. Tuban & 77,499 & 529,193 & 34,841 & 195,546 & 103,306 \\
\hline 10 & $\begin{array}{l}\text { Kab. } \\
\text { Lamongan } \\
\end{array}$ & 71,839 & 619,213 & 68,323 & 207,839 & 124,720 \\
\hline 11 & Kota Kediri & 71,737 & 404,212 & 14,221 & 155,576 & 102,648 \\
\hline 12 & $\begin{array}{l}\text { Banyuwang } \\
\mathrm{i}\end{array}$ & 70,560 & 781,893 & 67,358 & 282,589 & 137,791 \\
\hline 13 & $\begin{array}{l}\text { Kab. } \\
\text { Bojonegoro }\end{array}$ & 69,859 & 609,156 & 38,450 & 250,912 & 150,876 \\
\hline 14 & $\begin{array}{l}\text { Tulungagu } \\
\text { ng }\end{array}$ & 62,589 & 647,318 & 54,386 & 172,518 & 139,021 \\
\hline 15 & $\begin{array}{l}\text { Kab. } \\
\text { Lumajang }\end{array}$ & 59,704 & 555,637 & 53,813 & 173,987 & 111,707 \\
\hline 16 & $\begin{array}{l}\text { Kab. } \\
\text { Mojokerto }\end{array}$ & 58,228 & 530,750 & 48,153 & 156,343 & 82,712 \\
\hline 17 & $\begin{array}{l}\text { Kab. } \\
\text { Nganjuk }\end{array}$ & 57,537 & 543,722 & 59,215 & 187,779 & 135,928 \\
\hline 18 & Kab. Kediri & 56,456 & 710,271 & 36,602 & 292,031 & 124,704 \\
\hline 19 & Kab. Blitar & 50,683 & 653,427 & 63,755 & 225,411 & 116,682 \\
\hline 20 & $\begin{array}{l}\text { Kab. } \\
\text { Magetan } \\
\end{array}$ & 41,945 & 509,212 & 53,071 & 160,452 & 88,784 \\
\hline 21 & $\begin{array}{l}\text { Kab. } \\
\text { Sumenep }\end{array}$ & 41,753 & 570,982 & 37,056 & 197,122 & 127,865 \\
\hline 22 & $\begin{array}{l}\text { Kab. } \\
\text { Ponorogo } \\
\end{array}$ & 39,919 & 501,371 & 52,091 & 179,206 & 101,478 \\
\hline 23 & $\begin{array}{l}\text { Kota } \\
\text { Probolingg } \\
\text { o } \\
\end{array}$ & 39,355 & 269,030 & 27,393 & 116,310 & 105,874 \\
\hline 24 & $\begin{array}{l}\text { Kab. } \\
\text { Trenggalek }\end{array}$ & 38,768 & 432,227 & 59,884 & 87,550 & 111,682 \\
\hline 25 & $\begin{array}{l}\text { Probolingg } \\
\mathrm{o}\end{array}$ & 38,267 & 565,900 & 54,111 & 183,772 & 117,891 \\
\hline 26 & \begin{tabular}{l|} 
Kab. \\
Bondowoso \\
\end{tabular} & 37,577 & 478,582 & 46,703 & 125,250 & 95,556 \\
\hline 27 & $\begin{array}{l}\text { Kab. } \\
\text { Bangkalan }\end{array}$ & 36,432 & 503,793 & 60,697 & 228,297 & 123,231 \\
\hline 28 & $\begin{array}{l}\text { Kab. } \\
\text { Pamekasan }\end{array}$ & 35,640 & 472,233 & 52,178 & 118,736 & 109,745 \\
\hline 29 & Kota Blitar & 35,564 & 228,180 & 23,527 & 90,324 & 85,762 \\
\hline 30 & Kab. & & & & & \\
\hline
\end{tabular}


152 MODERNISASI, Volume 9, Nomor 2, Juni 2013

\begin{tabular}{|c|l|r|l|r|r|r|}
\hline & Situbondo & 32,850 & 453,040 & 48,750 & 155,580 & 89,347 \\
\hline 31 & $\begin{array}{l}\text { Kab. } \\
\text { Madiun }\end{array}$ & 32,055 & 428,409 & 52,097 & 109,158 & 93,928 \\
\hline 32 & $\begin{array}{l}\text { Kab. } \\
\text { Sampang }\end{array}$ & 30,020 & 444,537 & 58,755 & 196,787 & 97,250 \\
\hline 33 & $\begin{array}{l}\text { Kota } \\
\text { Madiun }\end{array}$ & 27,267 & 281,958 & 21,371 & 94,803 & 55,437 \\
\hline 34 & $\begin{array}{l}\text { Kab. } \\
\text { Ngawi }\end{array}$ & 26,294 & 576,912 & 52,433 & 155,873 & 96,011 \\
\hline 35 & $\begin{array}{l}\text { Kab. } \\
\text { Pacitan }\end{array}$ & 25,358 & 436,123 & 52,362 & 142,612 & 69,549 \\
\hline 36 & $\begin{array}{l}\text { Kota } \\
\text { Mojokerto }\end{array}$ & 25,100 & 211,273 & 17,825 & 106,977 & 90,250 \\
\hline 37 & $\begin{array}{l}\text { Kota } \\
\text { Pasuruan }\end{array}$ & 23,784 & 236,953 & 24,932 & 104,299 & 62,152 \\
\hline 38 & Kota Batu & 22,077 & 232,811 & 23,197 & 109,932 & 55,508 \\
\hline
\end{tabular}

Sumber: Data Diolah

Tabel 3

Rata-Rata PAD, DAU, DAK, Belanja Modal dan Belanja Barang dan Jasa Pertahun Kota dan Kabupaten

Di Provinsi Jawa Timur Tahun 2006-2012 (Dalam Juta)

\begin{tabular}{|c|c|c|c|c|c|c|c|}
\hline ITEM & 2006 & 2007 & 2008 & 2009 & 2010 & 2011 & 2012 \\
\hline PAD & 45,262 & 53,281 & 63,290 & 77,740 & 93,222 & $\begin{array}{l}137,75 \\
6\end{array}$ & $\begin{array}{l}165,74 \\
2\end{array}$ \\
\hline DAU & $\begin{array}{l}361,03 \\
4\end{array}$ & $\begin{array}{l}432,97 \\
9\end{array}$ & $\begin{array}{l}500,26 \\
8\end{array}$ & $\begin{array}{l}503,55 \\
7\end{array}$ & $\begin{array}{l}514,86 \\
1\end{array}$ & $\begin{array}{l}570,10 \\
1\end{array}$ & $\begin{array}{l}704,64 \\
7 \\
\end{array}$ \\
\hline DAK & 16,997 & 18,035 & 30,281 & 38,003 & 23,621 & 32,464 & 28,856 \\
\hline $\begin{array}{c}\text { BELANJ } \\
\text { A } \\
\text { MODAL }\end{array}$ & $\begin{array}{l}472,87 \\
5\end{array}$ & $\begin{array}{l}153,89 \\
3\end{array}$ & $\begin{array}{l}181,58 \\
4\end{array}$ & $\begin{array}{l}210,90 \\
9\end{array}$ & $\begin{array}{l}151,97 \\
9\end{array}$ & $\begin{array}{l}199,06 \\
5\end{array}$ & 50,206 \\
\hline $\begin{array}{c}\text { BELANJ } \\
\text { A } \\
\text { BARAN } \\
\text { G DAN } \\
\text { JASA }\end{array}$ & 91,695 & $\begin{array}{l}147,03 \\
9\end{array}$ & $\begin{array}{l}166,71 \\
4\end{array}$ & $\begin{array}{l}151,94 \\
9\end{array}$ & $\begin{array}{l}172,03 \\
1\end{array}$ & $\begin{array}{l}239,67 \\
0\end{array}$ & $\begin{array}{l}275,09 \\
1\end{array}$ \\
\hline
\end{tabular}

Sumber: data Diolah

Berdasarkan Tabel 3 menunjukkan bahwa PAD kota dan Kabupaten di Jawa Timur terus mengalami peningkatan, demikian juga alokasi dana dari Pemerintah Pusat yang berupa Dana Alokasi Umum (DAU) juga mengalami 
kenaikan yang signifikan. Sedangkan alokasi dana dari Pemerintah Pusat yang berupa Dana Alokasi Khusus mengalami fluktuasi.

Berdasarkan hasil pengolahan data menunjukkan bahwa data berdistribusi Normal (Gambar 3).

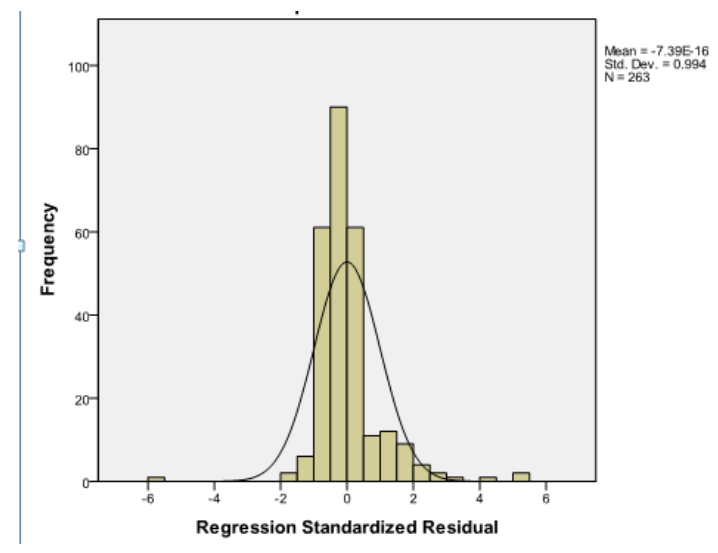

Gambar 3 Normalitas Data

Analisis Korelasi

Tabel 4

Korelasi antara PAD, DAU, DAK, Belanja Modal dan Belanja Barang dan Jasa

\begin{tabular}{|l|l|r|r|r|r|r|}
\hline \multicolumn{2}{|l|}{} & PAD & DAU & DAK & BEMOD & BELBARJA \\
\hline PAD & Pearson Correlation & 1 & .309 & .071 & .417 & .950 \\
\hline & Sig. (2-tailed) & & .000 & .254 & .000 & .000 \\
\hline DAU & Pearson Correlation & .309 & 1 & .649 & .071 & .417 \\
\hline & Sig. (2-tailed) & .000 & & .000 & .249 & .000 \\
\hline DAK & Pearson Correlation & .071 & .649 & 1 & -.172 & .151 \\
\hline & Sig. (2-tailed) & .254 & .000 & & .005 & .014 \\
\hline
\end{tabular}

Sumber: Data Diolah

Berdasarkan tabel 4 Menunjukkan bahwa hubungan antara PAD dengan Belanja Modal sebesar 0.417 sedangkan PAD dengan Belanja Barang dan Jasa sebesar 0.950. Hal ini menunjukkan bahwa hubungan antara PAD dengan Belanja Barang dan Jasa sangat erat. Sedangkan hubungan antara DAU dengan Belanja Modal sebesar 0.071 sedangkan DAU dengan Belanja Barang dan Jasa sebesar 0.417. Hungan antara DAK dengan Belanja Modal sebesar -0.172 dan DAK dengan Belanja Barang dan Jasa sebesar 0.151. 


\section{Pengujian Hipotesis}

\section{Hasil Uji Regresi Pengaruh PAD, DAU, dan DAK Terhadap Belanja Modal}

Berdasarkan hasil pengujian regresi PAD, DAU, dan DAK terhadap Belanja Modal seperti disajikan pada Tabel 5 menunjukkan bahwa Nilai koefisien determinasi sebesar 0.228. Artinya variable PAD, DAU, DAK mampu menjelaskan variasi Belanja Modal sebesar 22.8 persen, sedangkan sisanya 77.22 persen dijelaskan factor lain di luar model. Sebagaimana diketahui bahwa belanja Modal merupakan pengeluaran Pemerintah Daerah yang sarat dengan nuansa politik, sehingga factor politik akan mempengaruhi belanja modal yang dilakukan oleh Pemerintah daerah.

Tabel 5

Hasil Analisis Regresi PAD, DAU, dan DAK Terhadap Belanja Modal

\begin{tabular}{|l|r|r|r|r|}
\hline & \multicolumn{1}{|c|}{ B } & \multicolumn{1}{c|}{$\mathrm{t}$} & \multicolumn{1}{c|}{ Sig. } & VIF \\
\hline (Constant) & 200760.112 & 5.651 & .000 & \\
\hline PAD & .416 & 6.775 & .000 & 1.141 \\
\hline DAU & .167 & 1.931 & .055 & 1.960 \\
\hline DAK & -2.673 & -4.054 & .000 & 1.783 \\
\hline Dependent Variable: BEMOD & & & \\
$\mathrm{R}^{2}: 0.228$ & & & \\
F Hit $: 25.519$ & & & \\
Prob.: 0.000 &
\end{tabular}

\section{Pengujian Simultan (Uji Statistik F)}

Secara simultan variabel PAD, DAU dan DAK berpengaruh secara signifikan terhadap Belanja Modal. Hal ini ditunjukkan dengan nilai $\mathrm{F}$ hitung sebesar 25.519 dengan Probalitas sebesar 0.000, hal ini menunjukkan bahwa secara simultan atau bersama-sama variabel PAD, DAU dan DAK berpengaruh terhadap Belanja Modal.

\section{Pengujian Parsial (Uji Statistik t)}

Sedangkan secara Parsial menujukkan bahwa variabel PAD dan DAK berpengaruh signifikan dengan tingkat keyakinan 0.05, sedangkan DAU signifikan pada tingkat keyakinan 0.10 .

Berdasarkan hasil pengujian regresi, maka dapat dibentuk persamaan regresi sebegai berikut:

$$
Y_{1}=200760.112+0.416 X_{1}+0.167 X_{2}-2.673 X_{3}
$$

\section{Hasil Uji Regresi Pengaruh PAD, DAU, dan DAK Terhadap Belanja Barang dan Jasa}

Berdasarkan Tabel 6 hasil pengujian regresi PAD, DAU, dan DAK terhadap Belanja Barang dan Jasa menunjukkan bahwa Nilai koefisien determinasi sebesar 0.920. Artinya variable PAD, DAU, DAK mampu menjelaskan variasi Belanja Barang dan Jasa sebesar 92 persen, sedangkan sisanya 8 persen dijelaskan faktor 
lain di luar model. Hal ini menunjukkan bahwa PAD, DAU dan DAK merupakan komponen yang sangat penting dalam menentukan besar kecilnya pengeluaran barang dan jasa yang dilakukan oleh Pemerintah Daerah.

Tabel 6

Hasil Analisis Regresi PAD, DAU, dan DAK Terhadap Belanja Barang dan Jasa

\begin{tabular}{|l|r|r|r|r|}
\hline & B & \multicolumn{1}{|c|}{ T } & Sig. & VIF \\
\hline (Constant) & 22126.777 & 2.715 & .007 & \\
\hline PAD & .683 & 48.465 & .000 & 1.141 \\
\hline DAU & .112 & 5.677 & .000 & 1.960 \\
\hline DAK & -.023 & -.150 & .881 & 1.783 \\
\hline Dependent Variable: BELBARJA & & & \\
$\mathrm{R}^{2}: 0.920$ & & & \\
F Hit : 998.125 & \\
Prob.: 0.000 & & & \\
\end{tabular}

\section{Pengujian Simultan (Uji Statistik F)}

Secara simultan variabel PAD, DAU dan DAK berpengaruh secara signifikan terhadap Belanja Barang dan Jasa. Hal ini ditunjukkan dengan nilai $\mathrm{F}$ hitung sebesar 998.125 dengan Probalitas sebesar 0.000, hal ini menunjukkan bahwa secara simultan atau bersama-sama variabel PAD, DAU dan DAK berpengaruh terhadap Belanja Barang dan Jasa.

\section{Pengujian Parsial (Uji Statistik t)}

Sedangkan secara Parsial menujukkan bahwa variabel PAD dan DAU berpengaruh signifikan terhadap Belanja Barang dan Jasa dengan tingkat keyakinan 0.05, sedangkan DAK tidak berpengaruh signifikan terhadap Belanja Barang dan Jasa.

Berdasarkan hasil pengujian regresi, maka dapat dibentuk persamaan regresi sebegai berikut:

$$
Y_{1}=22126.777+0.683 X_{1}+0.112 X_{2}-0.023 X_{3}
$$

\section{PEMBAHASAN}

\section{Pengaruh PAD terhadap Belanja Modal}

Berdasarkan hasil olah data yang disajikan apada tabel 5 menujukkan bahwa Pendapatan Asli Daerah berpengaruh terhadap Belanja Modal. Hal ini Dengan demikian hipotesis kedua yang menyatakan bahwa PAD mempunyai pengaruh positif terhadap belanja modal dapat diterima. Hal tersebut sejalan dengan hasil penelitian yang dilakukan oleh Darwanto \& Yustikasari (2007), Solikin (2007), Putro (2011) Kusnandar maupun Siswantoro (2012) dimana Pendapatan Asli Daerah memiliki korelasi positif dan signifikan terhadap belanja modal. Namun tidak sejalan dengan penelitian yang dilakukan oleh Abdullah \& Halim (2006). 
Pendapatan Asli Daerah di kota dan Kabupaten di Jawa Timur sangat bervariasi, di mana koat-kota besar cenderung mempunyai PAD yang cukup tinggi. Walaupu persentase PAD cukup kecil dari total pendapatan yang diterima oleh daerah namun demikian PAD sangat berpengaruh terhadap pengalokasian belanja modal. PAD selama tahun 2006-2012 di Kota dan Kabupaten Di Jawa Timur menunjukkan kecenderungan mengalami peningkatan.

Sebagaimana hasil analisis statistic yang menunjukkan bahwa PAD berpengaruh positif terhadap Belanja Modal, maka daerah diharapkan dapat lebih mengoptimalkan penerimaan daerah. Oleh karena itu daerah hendaknya lebih terpacu lagi untuk memanfaatkan sumber daya daerah untuk dapat digunakan dalam rangka kegiatan yang dapat meningkatkan pendapatan. Daerah diharapkan dapat meningkatkan dan menggali potensi-potensi yang mampu menjadi sumber PAD yang sesuai dengan perundan yang berlaku. PAD yang semakin besar akan mampu memberikan keleluasaan kepada daerah untuk mengalokasikan ke kegiatan atau pengeluaran yang dapat memberi dampak terhadap peningkatan pembangunan dareh terutama pembangunan infrasturktur. Peningkatan alokasi belanja modal dalam bentuk aset tetap seperti infrastruktur dan peralatan merupakan hal yang sangat penting untuk meningkatkan produktivitas prekonomian karena semakin tinggi belanja modal semakin tinggi pula produktivitas perekonomian (Putro dan Pamudji, 2011). Sehingga selanjutnya akan berdampak dampak positif pada peningkatan pendapatan daerah, penyerapan tenaga kerja di daerah tersebut.

\section{Pengaruh DAU terhadap Belanja Modal}

Berdasarkan hasil olah data yang disajikan pada tabel 5 menujukkan bahwa Dana Alokasi Umum berpengaruh terhadap Belanja Modal. Hal ini berarti hipotesis 2 yang menyatakan bahwa DAU mempunyai pengaruh positif terhadap belanja modal dapat diterima. Hal ini mengindikasikan bahwa Dana Alokasi Umum yang selama ini diterima daerah telah digunakan untuk pembangunan infrastruktur dan sarana prasarana daerah yang yang terlihat dalam alokasi belanja modal. Hasil ini menunjukkan bahwa Dana Alokasi Umum bahwa semakin tinggi DAU yang diterima daerah maka akan semakin tinggi pula belanja modal yang akan dibelanjakan.

Hasil ini sejalan dengan hasil dari penelitian yang dilakukan oleh Harianto dan Adi (2007), Darwanto dan Yustikasari (2007), Solikih (2007) dan Abdullah dan Halim (2003) yang menyatakan Dana Alokasi Umum berpengaruh signifikan terhadap belanja modal, dan penelitian yang dilakukan Prakoso (2004) yang membuktikan secara empiris bahwa besarnya jumlah belanja modal dipengaruhi Dana Alokasi Umum yang diterima dari pemerintah pusat.

Pengaruh DAU terhadap belanja modal ini dapat mengindikasikan bahwa pelaksanaan otonomi daerah yang bertujuan untuk meningkatkan pelayanan publik yang direalisasikan melalui belanja modal juga ikut dibiayai oleh DAU tersebut. Bahkan Abdullah dan Halim (2006) menyatakan bahwa pendapatan dari pemerintah pusat berupa dana perimbangan di pemerintah daerah di Indonesia merupakan sumber pendapatan utama dalam APBD. DAU yang bersifat "Block Grant", memungkinkan daerah menggunakan sesuai dengan prioritas dan kebutuhan daerah untuk peningkatan pelayanan kepada masyarakat dalam rangka ontonomi daerah. 


\section{Pengaruh DAK terhadap Belanja Modal}

Berdasarkan tabel 5 menujukkan bahwa Dana Alokasi Khusus tidak berpengaruh terhadap Belanja Modal. Hal ini berarti hipotesis 3 yang menyatakan bahwa DAK mempunyai pengaruh positif terhadap belanja modal dapat tidak diterima. Hal ini mengindikasikan bahwa daerah mengalokasikan DAK bukan untuk membiayai barang-barang modal, hal ini tentunya sesuai dengan peruntukan DAK. Dimana DAK merupakan dana yang berasal dari APBN, yang dialokasikan kepada daerah untuk membantu membiayai kebutuhan khusus. Pengalokasian DAK memperhatikan ketersediaan dana dalam APBN, yang berarti bahwa besaran DAK tidak dapat dipastikan setiap tahunnya. DAK diberikan kepada daerah apabila daerah menghadapi masalah-masalah khusus. Menurut (Hairul Aswadi dalam Halim, 2001:58) menyatakan bahwa tujuan dari penggunaan DAK dapat diarahkan pada upaya untuk meningkatkan Indek Pembangunan Manusia (IPM) yang merupakan salah satu isu nasional yang perlu dituntaskan.

\section{Pengaruh PAD terhadap Belanja Barang dan Jasa}

Berdasarkan tabel 6 menujukkan bahwa Pendapatan Asli Daerah berpengaruh terhadap Belanja Modal. Hal ini Dengan demikian hipotesis 4 yang menyatakan bahwa PAD mempunyai pengaruh positif terhadap Belanja Barang dan Jasa dapat diterima. Pendapatan Asli Daerah di kota dan Kabupaten di Jawa Timur sangat bervariasi, di mana koat-kota besar cenderung mempunyai PAD yang cukup tinggi. Walaupu persentase PAD cukup kecil dari total pendapatan yang diterima oleh daerah namun demikian PAD sangat berpengaruh terhadap pengalokasian Belaja barang dan Jasa. Belanja Barang dan Jasa merupakan bagian dari Belanja Langsung yang dilakukan oleh Pemerintah Daerah, di mana Belanja Barang dan Jasa setiap tahunnya menunjukkan trend peningkatan.

Proposi Belanja Barang dan Jasa dari keseluruhan belanja yang dilakukan oleh Pemerintah Daerah berkisar 11\% - 30\%. Kota Surabaya pada tahun 2012 merupakan daerah dengan porsi Belanja Barang dan Jasa yang paling tinggi di Jawa Timur, yang mencapai 30\%. Sedangkan jika dibandingkan antara Belanja Barang dan Jasa dengan Belanja Modal setiap daerah tidak sama, ada yang lebih tinggi Belanja Barang dan Jasa atau sebaliknya.

\section{Pengaruh DAU terhadap Belanja Barang dan Jasa}

Secara statistic menunjukkan bahwa Dana Alokasi Umum berpengaruh terhadap Belanja Barang dan Jasa. Hal ini berarti hipotesis 5 yang menyatakan bahwa DAU mempunyai pengaruh positif terhadap Belanja Barang dan Jasa dapat diterima. Hal ini mengindikasikan bahwa Dana Alokasi Umum yang selama ini diterima daerah telah mendukung atau bahkan digunakan juga untuk membiayai pembelian barang dan jasa yang habis pakai untuk memproduksi barang dan jasa yang dipasarkan maupun yang tidak dipasarkan. Belanja barang dan jasa terdiri dari Belanja pengadaan barang dan jasa, Belanja pemeliharaan dan belanja perjalanan. Hasil ini menunjukkan bahwa Dana Alokasi Umum bahwa semakin tinggi DAU yang diterima daerah maka akan semakin tinggi pula belanja Barang dan Jasa yang dilakukan.

DAU yang berpengaruh terhadap Belanja Barang dan Jasa ini mengindikasikan pulan bahwa pelaksanaan otonomi daerah yang bertujuan untuk 
meningkatkan pelayanan publik yang direalisasikan melalui Belanja Barang dan Jasa juga ikut dibiayai oleh DAU tersebut. Seperti hal untuk belanja Modal, DAU juga digunakan untuk Belanja Barang dan Jasa, hal ini sebagai mana Abdullah dan Halim (2006) menyatakan bahwa pendapatan dari pemerintah pusat berupa dana perimbangan di pemerintah daerah di Indonesia merupakan sumber pendapatan utama dalam APBD. Daerah akan menggunakan DAU sesuai dengan prioritas dan kebutuhan daerah untuk peningkatan pelayanan kepada masyarakat dalam rangka otonomi daerah.

\section{Pengaruh DAK terhadap Belanja Barang dan Jasa}

Dana Alokasi Khusus diberikan Pemerintah Pusat kepada daerah apabila daerah menghadapi masalah-masalah khusus. Berdasarkan analisis statistic menujukkan bahwa Dana Alokasi Khusus tidak berpengaruh terhadap Belanja Barang dan Jasa. Hal ini berarti hipotesis 6 yang menyatakan bahwa DAK mempunyai pengaruh positif terhadap Belanja Barang dan Jasa tidak diterima. Hal ini menunjukkan hal sama seperti halnya pengaruh DAK terhadap Belanja Modal, di mana daerah mengalokasikan DAK bukan untuk membiayai belanja barang dan jasa dan juga belanja modal, hal ini sesuai dengan peruntukan DAK. Dimana DAK merupakan dana yang berasal dari APBN, yang dialokasikan kepada daerah untuk membantu membiayai kebutuhan khusus.

\section{KESIMPULAN}

Berdasarkan hasil analisis yang telah dilakukan dapat disimpulkan:

a. Pendapatan Asli Daerah (PAD), Dana Alokasi Umum (DAU), Dana Alokasi Khusus (DAK) secara simultan berpengaruh terhadap Belanja Modal Kota dan Kabupaten di Provinsi Jawa Timur.

b. Pendapatan Asli Daerah (PAD), Dana Alokasi Umum (DAU), Dana Alokasi Khusus (DAK) secara simultan berpengaruh terhadap Belanja Barang dan Jasa Kota dan Kabupaten di Provinsi Jawa Timur.

c. Variabel Pendapatan Asli Daerah (PAD) dan Dana Alokasi Umum (DAU) secara parsial berpengaruh terhadap Belanja Modal Kota dan Kabupaten di Provinsi Jawa Timur.

d. Variabel Dana Alokasi Khusus (DAK) secara parsial tidak berpengaruh terhadap Belanja Modal Kota dan Kabupaten di Provinsi Jawa Timur.

e. Variabel Pendapatan Asli Daerah (PAD) dan Dana Alokasi Umum (DAU) secara parsial berpengaruh terhadap Belanja Barang dan Jasa Kota dan Kabupaten di Provinsi Jawa Timur.

f. Variabel Dana Alokasi Khusus (DAK) secara parsial tidak berpengaruh terhadap Belanja Barang dan Jasa Kota dan Kabupaten di Provinsi Jawa Timur.

\section{Keterbatasan dan Saran}

Penelitian ini hanya menggunakan data kota dan kabupaten yang ada di Provinsi Jawa Timur, sehingga tidak melihat daerah-daerah yang merupakan daerah pemekaran. Selain itu penelitian ini hanya berdasarkan data-data kuantitatif, 
sehingga kurang dapat menginformasikan kebijakan-kebijakan anggaran yang diambil oleh Pemerintah Daerah dalam menentukan anggaran belanjanya.

Untuk penelitian selanjutnya dapat dilakukan penelitian dengan menggunakan data-data daerah pemekaran yang tentunya mempunyai karakteristik yang berbeda dan juga dapat memasukkan variable kebijakan anggaran yang sifatnya kualitaitif dan politis.

\section{DAFTAR PUSTAKA}

Abdullah, Syukriy \& Halim, Abdul. 2006. Studi atas Belanja Modal pada Anggaran pemerintah Daerah dalam Hubungannya dengan Belanja Pemeliharaan dan Sumber Pendapatan, Jurnal Akuntansi Pemerintah, 2, 17-32

Adi, Priyo Hari. 2005. Dampak Desentralisasi Fiskal terhadap Pertumbuhan Ekonomi (Studi pada Kabupaten dan Kota Se Jawa Bali). Jurnal Studi Pembangunan KRITIS. Universitas Kristen Satya Wacana. Salatiga.

Darwanto \& Yustikasari, Yulia. 2007. Pengaruh Pertumbuhan Ekonomi, Pendapatan Asli Daerah, dan Dana Alokasi Umum Terhadap Pengalokasian Anggaran Belanja Modal. Simposium Nasional Akuntansi $\mathrm{X}$, Makassar.

Halim, Abdul \& Muhammad Syam. 2012. Akuntansi Srktor Publik : Akuntansi Keuangan Daerah Edisi 4, Jakarta: Salemba Empat

Harianto, David dan Adi, Priyo Hadi. 2007. Hubungan Antara Dana Alokasi Umum, Belanja Modal, Pendapatan Asli Daerah dan Pendapatan Perkapita. Simposium Nasional Akuntansi X Unhas Makasar

Hendarmin. 2012. Pengaruh Belanja Modal Pemerintah Daerah dan Investasi Swasta terhadap Pertumbuhan Ekonomi, Kesempatan Kerja dan Kesejahteraan Masyarakat di Kabupaten/Kota Provinsi Kalimantan Barat. Jurnal EKSOS Volume 8, Nomor 3, Oktober 2012 hal 144 - 155

Kuncoro, Haryo. 2007. Fenomena Flypaper Effect pada Kinerja Keuangan pemerintah Daerah Kota dan Kabupaten di Indonesia. Simposium Nasional Akuntansi X, Makassar.

Mardiasmo. 2002. Otonomi dan Manajemen keuangan Daerah. Penerbit ANDI, Yogyakarta.

Nanga, Muana. 2005. Analisis Posisi Fiskal Kabupaten/Kota di NTT : Adakah Posisi Fiskal Lebih Baik. Jurnal Studi Pembangunan KRITIS. Universitas Kristen Satya Wacana. Salatiga. 
Nugraeni. 2011. Analisis Pengaruh Dana Alokasi Umum (DAU), Pengaruh Dana Alokasi Khusus (DAK) dan Pendapatan Asli Daerah (PAD) Terhadap Prediksi Belanja Daerah Studi pada Pemerintah Daerah Kabupaten/Kota di Indonesia. Akmenika UPY. Volume 8.

Prakosa, Kesit Bambang. 2004. Analisis Pengaruh Dana Alokasi Umum (DAU) dan Pendapatan Asli Daerah (PAD) terhadap Prediksi Belanja Daerah (Studi Empirik di Wilayah Propinsi Jawa Tengah dan DIY). Jurnal Akuntansi \& Auditing Indonesia, 8.

Republik Indonesia. 2004. Undang - Undang No. 33 Tahun 2004. Tentang Perimbangan Keuangan Antara Pemerintah Pusat dan Pemerintah Daerah.

. 2004. PP RI No. 3 Tahun 2004. Tentang Dana Alokasi Umum Daerah Provinsi, Daerah Kabupaten, dan Kota Tahun Anggaran 2005

\section{Perimbangan}

2004, PP RI No. 109 Tahun 2000. Tentang Dana

Saragih, Juli Panglima. 2003. Desentralisasi Fiskal dan Keuangan Daerah dalam Otonomi. Penerbit Ghalia Indonesia.

Setyawati, Anis dan Hamzah, Ardi. 2007. Analisis Pengaruh PAD, DAU, DAK, dan Belanja Pembangunan Terhadap Pertumbuhan Ekonomi, Kemiskinan, dan Pengangguran: Pendekatan Anlisis Jalur. Jurnal Akuntansi dan Keuangan Indonesia. Desember 2007, Vol. 4 No. 2 hal. 211-228.

Sulistyowati, Diah, 2011, Pengaruh Pajak Daerah, Retribusi Daerah, Dana AlokasiUmum, dan Dana Alokasi Khusus terhadap Alokasi Belanja Modal, studi pada Pemerintah Daerah Kabupaten/Kota di Jawa dan Bali, Fakultas Ekonomi UNDIP, Semarang. 